\title{
POLICY EVALUATION ON SECURITY TREATY (THE LOMBOK TREATY) BETWEEN REPUBLIC OF INDONESIA AND AUSTRALIA
}

\author{
Kaesorry M. Dari*, Candidat Doctor \\ University of Brawijaya, Indonesia \\ Hakim Abdul, Mardiyono, Makmur M. \\ Doctoral Program of Administrative Science, University of Brawijaya, Indonesia \\ *E-mail: darylkaesorry77@@gmail.com
}

\begin{abstract}
Bilateral cooperation on security treaty and other treaties in any form must be based upon trust among parties involved. The inter-trusted sense will be easier to be developed if those parties having some similarities especially in their cultural dimensions. On the contrary, if the two countries having significant differences, such as culture, history, level of social development, economic and technological developments it would be difficult to build the sense of trust and respect with each other. The study on the entire focus of research used a qualitative approach, through in-depth-interview techniques and documentation of secondary data in the data collection process. Then the data were analyzed using the interactive model. So, policy implementation performance in the form of bilateral cooperation between heterogeneous countries in many aspects will be determined by answering the question to what extent is one country's people able to perceive positively toward the other country's people. The result of this research are; first, the process of drafting the bilateral security cooperation policy that produces a particular product policy, influenced by three factors such as: the policy base used in the process of drafting the policy, actors involved in the process of developing policy, and bargaining positions of related country upon other countries. Second, the success of bilateral security policy process determined by the perspectives or meaning that is given to the policy substance and the role of actors. Third, The impact of the bilateral security policy against a country not only military security, but also non-military security.
\end{abstract}

\section{KEY WORDS}

Bilateral cooperation, security treaty, policy evaluation, Indonesia, Australia, Lombok.

According to Keating (2000) when New Order Administration assume in power over the Old Order Soekarno administration was the most advantageous moment to Australia post the $2^{\text {nd }}$ World War. Without the emergence of Indonesian administration that's more focus on social economic development and commit to create cooperation with neighboring countries in Southeast Asian region, Australia would face three decades with full of threat, uncertain, and would certainly expending budget for the development of its defense capacity.

These reasons become basic consideration of Australia to build a kind and close cooperation with Indonesia. But in this relation, there are some issues especially related to misunderstanding, such as different perception among them, including Australia suspects upon Indonesia as national threat due to the Indonesian foreign policy in the past that was confrontational. According to Evans (1993), problems of that relations was due to the lack of balance point that hold the relation in stable condition. For him, these balance power must be at various level both intra government, non government organization, as well as intra community between the two states. In this relation, he assumes that these levels can build networking which if one of the networks is facing problem, another network is able to unite both countries while problematic level is being fixed.

According to William (2001), in the interest to keep a balance policy and to avoid excessive strategic alliance with world super power, Indonesia always claims as non US 
coalition. Then, in December 1995 Indonesia tied formal security agreement with Australia. On the initial perspective of Indonesia, having an agreement with Australia was a constructive movement of its foreign policy by considering a couple of main reason; first, such agreement gives an alternative way to Indonesia in expanding its security and foreign policy, out of ASEAN tradition and without directly involved in super power competition. Secondly, it signaled to China that Indonesia could and would intensify its maritime security network to prevent what is considered by Indonesia to be hegemonic tendency in major sea shore and islands in Southeast Asia. Thirdly, the agreement is beneficial as confidence building measurement to convince Australia that Indonesia is not expansionist threat from Southeast Asia region as well as Southwestern Pacific (to Papua New Guinea). Fourthly, by affiliating to one of the US closest security alliances in the Asia-Pacific, the treaty uplifted Indonesia closer to US security network without necessarily enter strategic alliance with US formally.

The collapse of the Twin Tower of the World Trade Center (WTC), New York and the attack of Pentagon, the headquarters of the United States Department of Defense, in September 11, 2001, terrorism issues was since then considered to be a very important of the international agenda. The terrorism attack regenerate a change of paradigm change on security and national threat especially to US and its alliance countries. Since the 9/11 attacks the cooperation between Indonesia-Australia against global terrorism was initiated for the first time and agreed upon a Memorandum of Understanding on Combating International Terrorism. The MoU was a common action done by the two parties to follow up on the US foreign policy against terrorism. In the MoU stated that both countries could share intelligence information exchange in the effort to prevent, eradicate and fight against international terrorism.

Terrorism issue amounted to its peak following the 2002 Bali bombing on October and resulted a negative image from international community to Indonesia that was assumed as 'a terrorist nest.' In order to counter such international assumption, Indonesian government attempt to build and to create the role of Indonesian community in various international cooperation that was oriented to achieve national interest to rebuild its image and achieve the international trust.

During first period of Susilo Bambang Yudoyono administration October 2004 to 2009, Indonesia and Australia relations indicated that a good relations between the countries will be formed. This condition based on some reasons, such as a close personal relation between the two leaders, there had been discussion with Australian government before his presidency. Beside, there were some good points owned by Susilo Bambang Yudoyono that convince Australia to think positively about Indonesia. Due to this close and influential relationship of Indonesia and Australia, in 2005 the Prime Minister John Howard stated that: "Australia's bilateral relationship with Indonesia is a strategically important and very close one covering trade and investment security, intelligence and police cooperation, development cooperation, education and extensive people to people ties". (Angraeni, 2006).

However, some internal challenges remain exist during the period of Susilo Bambang Yudoyono administration. Those challenges include corruption issues, law enforcement and economic growth. Beside, Indonesia has to prevent misunderstanding upon international perception on international terrorism movement that occurred many times in last couple of years in Indonesia. Especially when Bali bombing II on October 1, 2005 causing the deficiency of the international community trust to Indonesia as Indonesia was assumed to be fail in countering terrorism. There were some reasons for the Indonesian government weakness and causing terrorists conducted their actions in Indonesia especially in Bali, such as the weakness on the related law, low level of education, high poverty rates, limited quality and capacity of the state intelligence institution. These four reasons made Indonesia as the most desirable place for terrorists to conduct their operations.

In this relation, during the period of the President SBY administration, terrorism issues became high priority and focusing on the effort to increase contra-terrorism cooperation especially with Australia, implemented by making new contra-terrorism policy to ensure the Indonesian national security (Wise, 2005:44). This new contra-terrorism policy was expected 
to be able to conduct harmonious relations between the two countries. One of them was Aviation Security Capacity Building Project that had been signed on March, 2005 (Wise, 2005:74), as an attempt to prevent any access of terrorists into Indonesia via sea and ground channels through border lines.

On 3 - 6 April 2005, a bilateral meeting took place to sign Joint Declaration of Comprehensive Partnership between Indonesia and Australia by President Susilo Bambang Yudhoyono and PM John Howard in Australia. Both countries also agreed to form a new security framework intended to strengthening cooperation in security and supported the policies in various parts of Indonesia. The signing over the treaty of security cooperation framework done on November 13, 2006 known as the Lombok Treaty, the name originated where the event done, i.e. Lombok-West Nusa Tenggara. The document of treaty covered wide range of fields such as defense, law enforcement, terrorism eradication, intelligence cooperation, maritime cooperation, aviation safety and security, weapon of mass destruction deployment, natural disaster search and rescue, and people to people link. The extent to the policy implementation of bilateral cooperation the Lombok Treaty, and factors that inhibit its implementation are to be focus of this research.

\section{THEORETICAL REVIEW}

In the traditional concepts, scientists tend to interpret security as free from all forms of dangerous threats, worries and fears as no physical (militarily) threat condition derived from outside. Lippmann (1943) summed up this tendency by stating: "a nation is secured to extend to which it is not in danger of having to sacrifice core values, if it wishes to avoid war, and able, if challenged, to maintain them by victory in such war."

Three important characteristics of the traditional security are: first, identifying 'national' as 'state'; second, threat is assumed as derived from outside of the state; and third, deployment of military forces to counter such threats. Wolfers (1952:484) concluded that major problem faced by every state is to build forces to deter or to defeat an attack.

In contrast to the traditional concept, contemporary discourse defines security in an inflexible manner and easy by including elements and perspectives of non military, but refers to all dimensions that determine state existence, including attempt to strengthening internal security through nation-building, food sufficiency, health facility, finance and trade, as well as nuclear weapon development. In this context, Thomas and Mathews recognize the existence of the non-military threat, but they do not fully leave tradition that assume a state as the most important entity. Their contributions lied particularly on security scope that no more limited on the military dimension. As a consequence of contemporary concept on security, the following terms come out such as; environmental security, food security, energy security, economic security, and human security, which showing that social and/or political entities could encounter threat in various fields of life.

The threat could be derived from foreign as well as domestic, such as transnational threat which is an outside threat but be able to resonate domestically. Principally, this threat is derived from outside state border, but it can create serious problem in the national state territory. Transnational threat could threaten the security component that exist in a country, such as threatening ideational and institutional.

The common ground between contemporary discourse and traditional on the security concept is state adequateness. The government as a representative of the society to implement state policy have to fulfill that adequate staleness element, especially how to keep the balance between coercive capacity, infrastructural power and unconditional legitimacy.

Source of threat against national security becomes wider in scope, not only covering the internal and/or external threat but also global threat without being classified as internal or external threat. In line with it, nature of threat has also been changing to be multidimensional. Threat becomes plural and cannot be limited as military threat, ideological, political, economic and cultural threats. Similar to military threat, ideological or political threats can emerge in variety of forms, such as certain pressure to change the objectives, form or structure of its political institution. In its most extreme form, political threat occurs especially if 
there are differences in organizing principle among antagonistic states. For example, what Libya and Syria did toward some moderate government in Middle East such as Lebanon and Jordan, and America did against radical regimes in Latin America and Caribbean such as Cuba, Chile, Guatemala and Haiti. In softer form, political requirement that accompany all assistances bilaterally and multilaterally, can also be categorized as political threat. The more important of external threat is economic that sometime difficult to be defined clearly, because it seems ambiguous, non cross-boundary criteria and also at the same time does not meet the criteria to use the power.

What now days known as 'domestic security' can reach out to wider spectrum, starting from poverty, epidemic and natural disaster, social riots, criminals, inter-community clashes, armed separatist movement to armed insurgency. On the other hand, disturbance that occurs due to social gap could be assumed as serious threat toward human security, without to be the threat against the functioning of state government institutions and not a threat toward territorial integrity. Separatist movement that differ from armed insurgency is a direct threat relates to territorial integrity and the functioning of state government institutions.

Capacity to encounter dynamic global threat not only based on military capacity, but also the capacity of other element of national power, including government capacity to overcome them. Related government apparatus have responsibility to keep security, while military responsible to formulate things relate to defend tactic and operation. Certain threat must be encountered by instruments that appropriate, effective, efficient, and free from social dislocation, economic, political and ideological. The consideration on historical, geographical, ideological and contemporary political development must also be included into this calculation. The dynamics of relation between countries in economic dimension are not totally abolish the relevant context of geostrategic politics. As an archipelagic country like Indonesia, protecting national security is great endeavor to protect and to defend its maritime sovereignty with all existing resources. Sea line of communication, sovereignty of exclusive economic zone, and sovereignty over sea resources is as important as them in the ground. At strategic level, to defend from threat and existing challenges is to identify that challenge realistically. For the near future security over internal threat would still dominate the strategic thought in Indonesia. Due to social pluralism, economic disparities and regional disparities make national building and state building become serious problems. Indonesia is a political entity (a country) that is built on the foundation of plurality.

In the interdependency among nations, a state can not secure itself by threatening others. In order to actualize the same, the concept shifted from "security against' into "security with." What have been known as cooperative security, confidence building measures, and preventive diplomacy done bilaterally, globally as well as multilaterally is part of the efforts to answer this issue.

Essentially, partnership is a relation between two parties or more to achieve the objective. According to Teece (1992), partnership is "a formal cooperation among individuals, groups or organizations to achieve a certain goal or task". A good partnership is capable to get benefit or value added to those who conduct a cooperation, or in other word it can achieve a win-win solution." Value-added is not only in the forms of natural physics but also in the forms of increasing service capacity, (such as: education, training, manpower employment), increasing access, likes social cooperation, economic, education, security among cooperated states etc.

Basically, every country will face a limited territory because every country has geographical border recognized by all nations. It means that relation among nations prohibit one state to occupy over other state's territory. Limited territory leads every state devoting its own resources to increase the citizen welfare. It tends to strengthen itself by any means necessary such as economic, military-politic, and origin because of the assumption that foreign state can be a threat at anytime.

Linton (1995) argued some considerations that one state must cooperate with others, it is: "to achieve goals of common welfare (economic welfares, social, and maintaining common security) because some parties can not achieve them by themselves. Limited Resources (physical geography, social, economic) owned by each parties forcing to share 
their resources by cooperate to each other. Partnership is not always intended to achieve a joint objectives, but can also have different objectives. The most important meaning of the partnership is sharing resources and mutually beneficial.

According to Eisler, Rione \& Montuori (2001) there are several cooperation relationship model, first, domination relationship; it means the first party dominates the second one in carrying out the relationship. Second, subordination relationship, it means the second party control the first one, or the second party deliberately put themselves under the control of the first party in carrying out the relationship; and thirdly, partnership relationship, it means the first and second party are in the equal level where they resting on the trust, cooperation and respect each other.

Based on that explanation, theoretically the security cooperation between the Republic of Indonesia and Australia should be able to provide benefits on both sides in the aspects of politic, security, social and culture etc. Cooperation in the field of security based on background of resources and national interests between Indonesia-Australia will be able to meet the common interest, for example in the form of maintaining stability of the regional security, avoiding conflicts between the countries as well as a feeling of mutual respect in the aspects of defense and security. The cooperation not only provides benefits in the form of material, for example: the development of physical infrastructure and military weapons, but can also be in the form of capacity building, such as: improvement of bilateral relations, the improvement of the security service, courses, training, joint exercises that can be mutually beneficial (mutual benefit) to both parties.

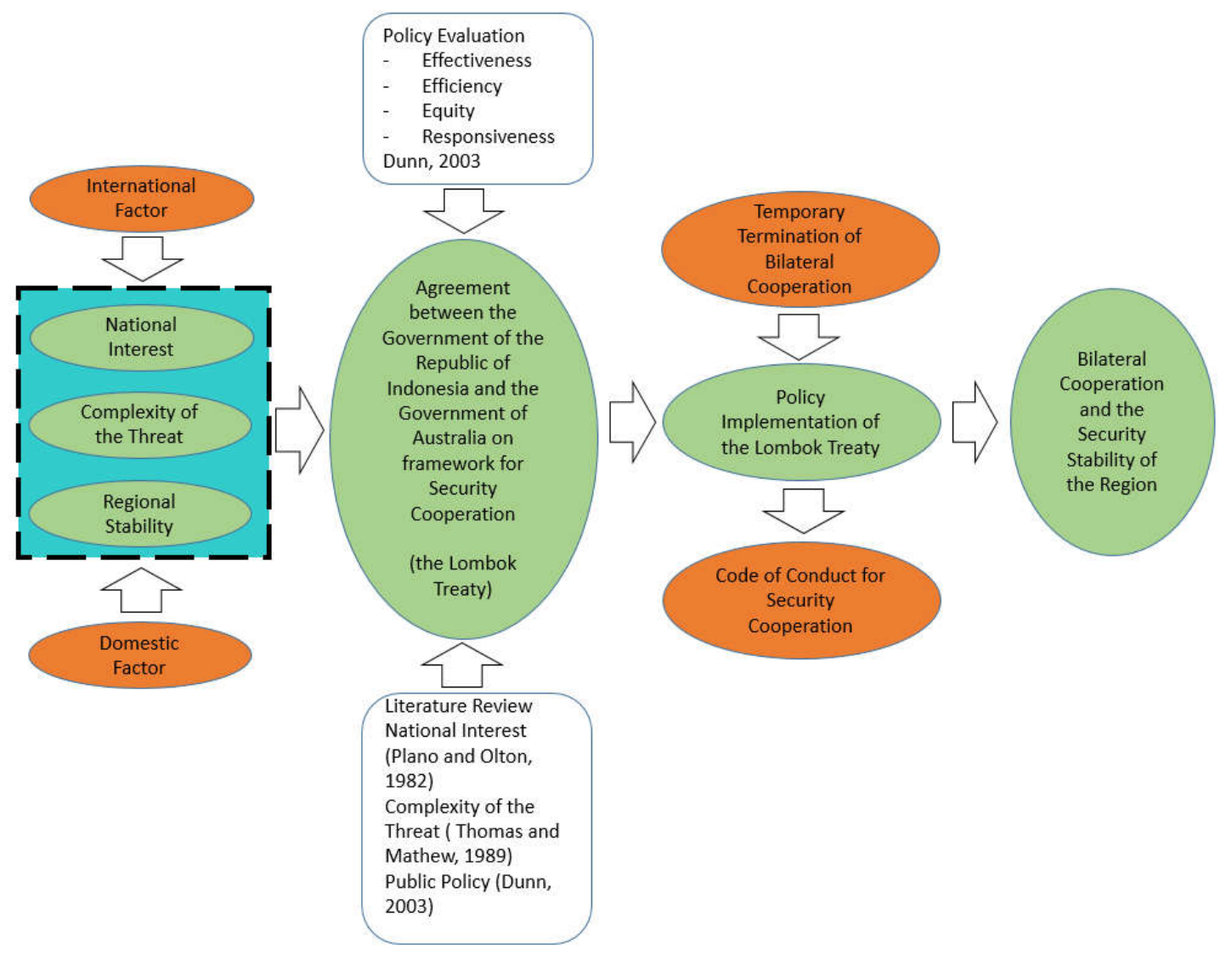

Figure 1 - Conceptual framework.

In addition to the theories related to defense and security, the study also deals with the analysis of public policy, because the Lombok Treaty is a policy product of the two countries, Indonesia and Australia. Researchers combine several theories of public policies, especially those related to public policy implementation model. Variables used by writer from the results of policy implementation model synthesis which is top-down, bottom-up, as well as other 
variables in which the most dominant in the process of implementation of public policy, they are: (a) actor or organization of the policy implementer; (b) the mechanism or working relationship between implementer organization; and (c) environmental or policy implementation arena.

According to Winarno, actors in the process of policy formulation can be divided into two groups; they are official and non-official actors. (Winarno, 2002). Actors included as official are government agents (bureaucracy) executive (President, Governor, Mayor), legislature and judiciary. While those involving in non official including supporting groups, political parties and citizens of the state, expert planner as well as other individual. The organizational structure analysis use the organizational structure model of analysis, where the implementer organization were grouped into four groups, they are: (a) vertical approaches, (b) horizontal approaches, (c) assistance structure approaches, and (d) lead agency structure approaches. Analysis of the policy implementation environment using environment synthetic theory model of Nugroho and Van Waarden, such as: (1) history, (2) politic, (3) defense and security, (4) financial ability/economic, (5) governmental administration, (6) national technology ability, (7) natural resources, (8) social and cultural (9) nature and weather, (10) other policy. All selected aspects are considered relevant to the issue of this research, and conceptually can be described below.

\section{METHODS OF RESEARCH}

The study on the entire focus of research used a qualitative approach, through indepth-interview techniques and documentation of secondary data in the data collection process. Then the data were analyzed using the interactive model (miles, et al., 2014), with the component of data analysis consisting: data collection, condensation data, display data, and conclusions. Through the use of this method, researcher formulates a theoretically proposition data based, and also empirical model of the defense cooperation implementation process 'The Lombok Treaty'.

\section{RESULTS AND DISCUSSION}

The Process of Security Cooperation Policy (The Lombok Treaty) Framework Formulation. The core policy that were used in preparing The Lombok Treaty, the first is foreign policy; a set of policy or any decision of the country to set the relationships with other countries by referring to the national interest of the concerning state. For Indonesia, foreign policy is policy, attitude and a step of the government of Indonesia taken for the purpose of building a relation with other country, international organization and any subject of international law to achieve national goals. So, Indonesian foreign politic is nothing but part of national politic descripted from the national intention and Indonesia national goals.

The second base is a common principles owned by Indonesia and Australia to see that regional cooperation or international level is the way to increase national and regional security as well as the purpose of United Nation in achieving world peace, especially peace in the zones of Asian region (Moertopo, 1974).

The other base is a commitment to sovereignty, unity, independence and integrity of the territorial between the two countries to stay stable in Asia Pacific region, as well as the commitment not to be meddled in other country domestic affairs. Actually, the cooperation between Indonesia and Australia has been lasted since 1968, then the cooperation was set out to be Indonesia-Australia Defense Cooperation Program (DCP). The DPC establishes yearly regular meeting program and a routine joint military training between the two countries.

The fourth base is each country national interest. The Lombok Treaty mentioned one of the national interests such as the interest to eradicate security threat, whether they are in the sense of traditional or non-traditional threat. In this relation, the two countries need to increase their own capacity. 
During the period of president SBY, the Joint Declaration on Comprehensive Partnership between the Republic of Indonesia and Australia was initiated. This declaration mentioned that the two countries have a commitment to enhance cooperation in the economic and technical sector, security cooperation, as well as to increase interaction between the societies. This declaration also mentioned the importance of cooperation to crack down terrorism that become the mutual concern, especially after the incident of the first Bali bombing in 2002. To this purpose, both countries have agreed to conduct cooperation in order to increase police capabilities, intelligence information exchange, and also cooperation in the immigration and customs. In addition, commitment to conduct close cooperation in the sector of maritime and maintain the security of sea area also become the main priority in respond to transnational crime threat which was commonly committed by sea transportation.

If we analyze a security agreement of the Lombok Treaty with the theory of neorealism, then we can also get the meaning of the security agreement of Lombok Treaty. Neorealism is the improvement of the realism theory, that perceiving the international relations as anarchy and positioning the country as the actor but not the main actor. According to neorealism, the main actor is international system. But not forever neorealist use the anarchy way in retaining its power. They use institution to gain the power. To achieve the power, neorealist people explained that all of the state must be associated with relative gains resulting from the efforts of agreement and international cooperation. In carrying out this cooperation, the neorealist applying zero sum system that include definition of agreement or treaty must give an advantage for neorealist people.

The role of actors in the implementation of policy is very important and is a key to the success of the policy. Holsti explained that the formulation of foreign purpose can not be separated from the role of actors in formulating them. Holsti also stated in order to understand a foreign policy as a whole, we need to put ourselves as policy makers and try to identify the objectives and interests, also understanding why policy makers choosing this various strategies and action to preserve or otherwise changing the situation. Policy and the other actors behavior (the policies and actions of other states) refers to the response or reaction from other countries upon the country in problem. For example of this case, in addition to Indonesia and Australia, is there another country that is actively participate or at least giving a respond to the Lombok Treaty security cooperation.

The role of actors for the policy implementation of The Lombok Treaty could also be analyzed from Edward III (1980) policy implementation model. According to Edward III, when bureaucratic structure is not conducive to the policy, it will cause the resources to be ineffective and impeded the implementation of policy. This bureaucratic structure includes some aspects, such as: organizational structure, division of authority, the relationship between units of related organization, and so the organizational relationship with other organization etc. Bureaucratic structure includes fragmentation dimension and standard operational procedure that will ease and homogenize the action of those responsible for implementation of the policy and carry out the related field. This dimension asserts that fragmented bureaucratic structure can increase the failure of the communication. In other words, fragmented organization will experience distortion in implementing the policy. In the context of implementation process of the Lombok Treaty, bureaucratic structure is elaborated in the authority of each institution of the two countries, namely foreign ministry, defense ministry, and other ministry related to the implementation of The Lombok Treaty. Coordination and communication inter institutions determined by each ministry of foreign affairs of the country, which serves as leading sector in any process of program implementation.

Policy implementation of The Lombok Treaty, obtained significant support from certain institutions such as:

- Defense Ministry, prepared an agenda of action plan to improve the quality of human resources in the field of diplomacy, i.e. in the form of modern management application, sending personnel to participate in various regional and international forum; 
- Defense Ministry in cooperation with the ministry of State Owned Enterprises (SOE) undertaking efforts to revitalize defense industry. The Defense Ministry push the Ministry of Finance to give incentives made specifically for national defense industry who actively contributed for the modernization of defense equipment. The defense Ministry is also in collaboration with other government agencies to modernize its defense equipment's, such as: Lapan, PT. Len industry, PT Pindad, PT PAL, and PT Dahana etc.

- Defense Ministry involving academician community from various colleges to implement an evaluation on defense diplomacy, and fully handle the Defense Attaché affairs that has been managed by BAIS TNI in order to optimize the defense diplomacy;

- Defense Ministry along with TNI headquarters, Army headquarters, Navy Headquarters and Air Force headquarters conducting close coordination to evaluate Defense Ministry-TNI internally in relation to defense cooperation that had been interwoven with other countries, issued blueprints of defense diplomacy after going through the process of drafting that involve all stakeholders of defense diplomacy; and promote the formation of Central Diplomacy of National Defense which is under the Defense Ministry as an organization to develop the concept of Indonesian defense diplomacy;

- Defense Ministry and TNI headquarter conducting evaluation of the defense cooperation performance especially to optimize defense cooperation in the border area according to the intelligence, operations and exercise, personnel and logistics.

The role of the defense ministry capacity in the process of the Lombok Treaty implementation can be explained from the perspective of Ripley and Franklin (1982), stating that the success of policy implementation determined by three factors:

- Compliance from street level bureaucrats to their superior in the operationalization program on the Defense Ministry, so that The Lombok Treaty terms can be implemented relatively right;

- Consistence in routine and absence of problems, either in coordination and communication between the Defense Ministry and the Ministry of Foreign Affairs and the other related ministry;

- Satisfactory to the performance of the Ministry, as predicted by the Indonesian government and Australia.

Factors that inhabit the process of the Lombok Treaty implementation are:

- The quality of human resources that are low, especially from Indonesia, not only in relation to the ability of mastery a foreign language, but also academic ability to support the establishment of the defense diplomacy purpose. Consequently, it's often that Indonesia to be in unfavorable position of the defense diplomacy, and facing difficulties to propose any new developments in the innovative multilateral defense cooperation;

- Limited standard of defense equipment, so that the cooperation program in the field of operations and exercise has not yet been optimized, and also affect the testing of equipment ability that involve an advance scenarios in joint exercises with other countries.

The impediment factors can be explained in the theory of strategic asymmetry. Strategic asymmetry makes cross-border cooperation in the security field became increasingly difficult, because of differences in each country, for example demography and military differences. The difference in the level of education, technology, and also homogeneity and the regional heterogeneity is also become the influencing factors to persistence of cooperation between the countries. (Singh, 2002, Metz, 2001). When Australia use its superiority, ability, and technology to affirm the superiority over Indonesia, so strategic asymmetry between Indonesia and Australia is in the positive dimension. On the contrary, when Australia use its superiority to give threats and to disturb Indonesia, then strategic asymmetry is in the negative dimension. Australian military training cooperation for 
the Indonesian military personnel is superiority in positive dimension. But, the Australian policy in some cases such as turn-back boat policy to the water area and violating the boundaries of Indonesia is strategic asymmetry in negative dimension.

Implementation Model of Indonesia-Australia Bilateral Defense Cooperation. The implementation of Lombok Treaty has not been going effectively, as there are many impediment factors. First, the differences in the interests of between Indonesia and Australia. Among the ten points of Lombok Treaty that had been approved by the two countries, not all of them constitute the interests of each country. Indonesia has interest in several points of the treaty, while Australia also has interest by themselves in several other points of the treaty. As a consequence of the distinction on interests, the focus of each country in implementing the security cooperation agreement can not be fully optimized.

The second factor, the opposite perception between Indonesia and Australia. A cooperation can be successfully implemented if the parties involved having the same perception. In the context of relations between Indonesia and Australia, the perception between the two countries is difference. In fact, the perception between them is mutually incompatible.

The third factor, the asymmetry in the strategic force. Inequalities between Indonesian strategic forces and Australian strategic forces. According to research, the Australian strategic forces is superior compared strategic forces owned by Indonesia. A country with its superiority upon the strategic forces would tend to devalue the commitment of cooperation with other countries with the lower forces. A country having superiority on the strategic forces is likely more courageous to violate the cooperation agreement. In this relation, Australia more likely to be bold to violate the cooperation commitment of the Lombok Treaty, i.e. by tapping, violation of the boundaries, and issues related to immigrants without documents.

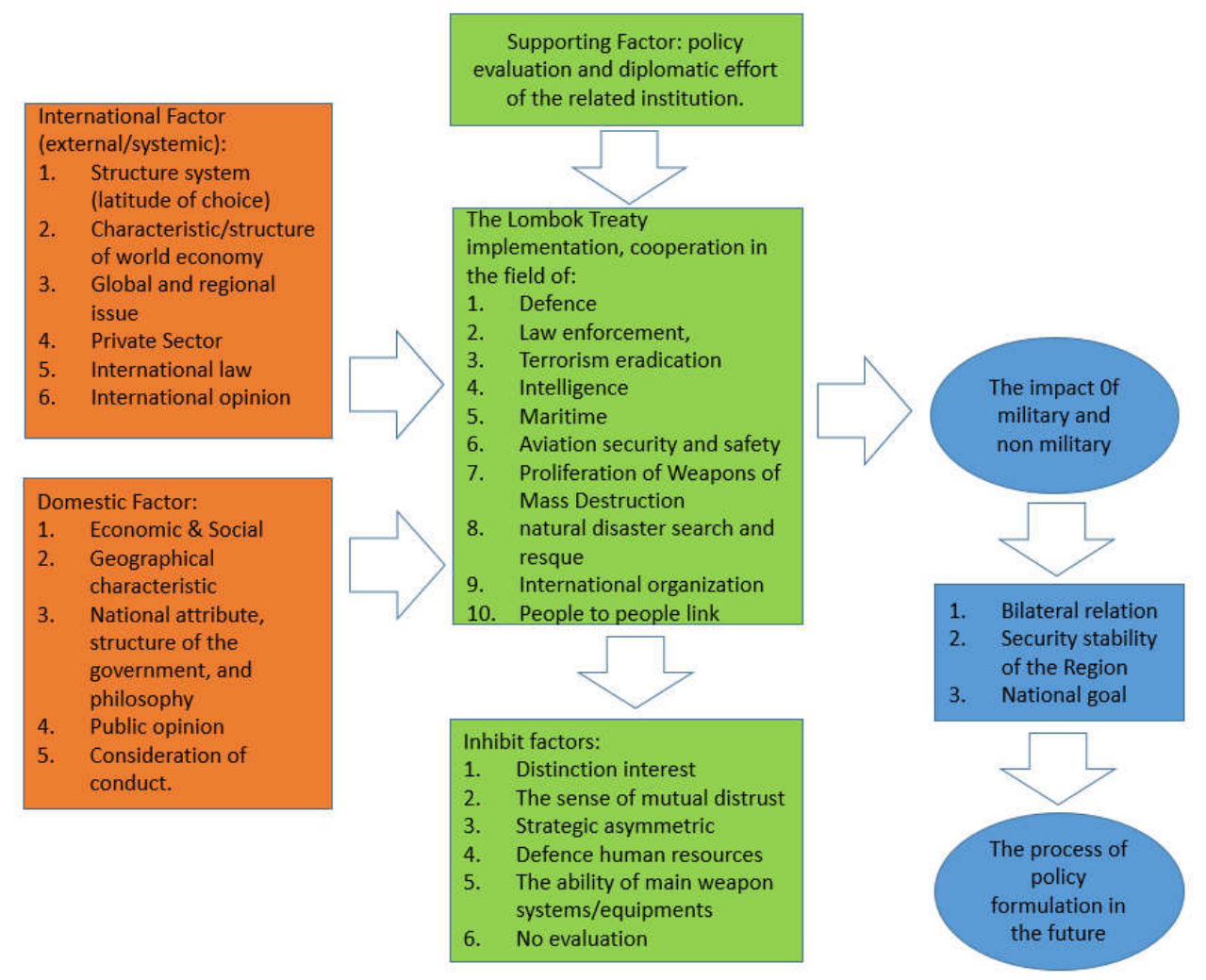

Figure 2 - Model of recommendation in the policy implementation of bilateral security cooperation Indonesia-Australia.

Based on the analysis of external factors, or factors coming from outside the state, researcher consider two most dominant external factors that influence the decision of 
Indonesia to sign the Lombok Treaty, they are: first, global and regional issues, such as terrorism, global warming, cross country security, and also the nuclear issue. But, the most significant issue for the security of Indonesia and Australia is terrorism. Second, the role and policy of other countries, in this matter, Chinese position was very drastic in economic resurrection, political influence, and also military power. This clearly initiate Indonesia and Australia at that time to prepare the defense and security as well as counteracting of any possibilities of worse scenario by Chinese. The rise of China to expand its hegemony in Asia can be seen by the addition of the quality and quantity of military power, increasing Chinese influence in Southeast Asia and Asia Pacific as counterbalance to the presence of US power in the area.

The other external factor like international economic factor at the time that could be considered of being stable, not exerting any significant influence for Indonesia to sign this Lombok Treaty. In other words, International economic condition were not really encouraged Indonesia to sign the Lombok Treaty. International public opinion wasn't also in significant effect on the policy to sign the Lombok Treaty. Public opinion was actually tend to be negative and pessimistic in respond to the Lombok Treaty, but the government of Indonesia decided to sign the treaty and even ratifying the Lombok Treaty in 2007.

Researcher analysis based on the empirical data in the field and theoretical analysis, the weakness of the Lombok Treaty implementation is the lack of attention on the emphasis of impact aspect. The impact of the treaty can be seen empirically to be the impact on military and nonmilitary, however, impact on nonmilitary security become one thing that were excluded from the implementation process.

\section{CONCLUSION AND RECOMMENDATIONS}

Based on the analysis and discussion that have been outlined in the earlier chapter, the conclusions can be drawn as follows:

- The process of drafting the bilateral security cooperation policy that produces a particular product policy, influenced by three factors such as: the policy base used in the process of drafting the policy, actors involved in the process of developing policy, and bargaining positions of related country upon other countries. Above these three factors, the aspect of national interest of the country which is included in the factor of policy base is a dominant factor that affects the formulation of bilateral security cooperation policy.

- The success of bilateral security policy process determined by the perspectives or meaning that is given to the policy substance and the role of actors, also to the forces that support and inhibit the process of policy implementation. Among the aforementioned factors, subjective factor which is a perception or meaning given to the state more dominant in influencing the success of policy implementation compared to the other factors.

Every actor involved in the implementation process of bilateral security policy impacted on the success of the sectors included in the cooperation. All related actors give meaning to the sectors included in the cooperation, in the sense of favorable to its national interests. While factors that support the policy implementation, especially the policy context that include three elements: power, interest and strategies of actors involved, because each country has the strategy, sources and authority position that determine the success of policy implementation.

The other aspect are compliance and responsiveness, its how the country being responsive to each interests and also to the aspects that can inhibit the achievement of policy goal. Factors that may inhibit are: low quality of human resources, limited ability of weapons/equipment, and the absence of comprehensive evaluation upon the policy implementation that has been experienced or previous cooperation. However, the main inhibit factor is come from other than policy; it is the problem from suspicion of each other and the existence of strategic asymmetry. 
The impact of the bilateral security policy against a country not only for military security, but also non-military security. In those two factors, the effects can be positive and negative. If the impact is interpreted as an adverse impact to national interests of participating states, then the country tend to stop the process of policy implementation, both unilaterally and on the basis of the agreement. While the impact on military and non-military security will be positive if considering these three factors, first, the implementation of the policy is significantly beneficial to strategic interest of two countries, not only beneficial or adverse to one of related parties; second, must be based on the spirit of partnership that equal to each other, not superior and lower or superior and inferior; third, the two countries should always being proactive and open in the partnership, not the other way around, or what other term call "two faced politic". The three requirement must be expected in order to ensure the sustainability of security cooperation of the two countries in the future.

Based on these conclusion, especially the factors that support and inhibit the process of the Lombok Treaty implementation, the researcher propose some recommendation as follows:

In further examination, the problems that arise mostly caused by the presence of issues that were taken to the political forum and eventually affect the diplomatic ties between the two countries. Because the security cooperation closely follow the politic development of the country, then the rise and fall in the security cooperation of the two countries is actually adhering to the development, not because of direct friction between the two armed forces. There is always possibility for the problems which happened in the past to be repeated in the future. Hence, what problems arose is not to be avoided, but in fact must be faced with the right solution, so that they do not continue to happen in the period of generation to come. For that, it is required an effort from all related parties to avoid the emergence of problem that might be able develop into large problem.

Issues related to the violation of human rights in Papua, and the existence of OPM that could inhibit relationship between the two countries, a dialogue is needed to avoid any dispute from this issue and encourage Australia to realize that there should be a political commitment from Australia not to support any separatist movement in Indonesia.

Addressing significant differences in culture and language can be quelled through some programs such as 'country presentation' in exchange forum and military education between the two countries. With this program, the military personnel of the two countries will gradually understand the advantages and disadvantages of each culture, and respect to each other culture.

Apparent attempt from the two countries military is needed in order to continue establishing defense cooperation based on equal partnership. However, words or theory is not that easy as its practice in the field. For that researcher recommend that active dialogue and communication between military official of the two countries could be improved further in the future. Besides evaluation on the cooperation programs that have been going on so far need to be initiated in order to ensure the cooperation really meets the requirement and enable to improve professionalism of the two countries military.

\section{REFERENCES}

1. Abidin, Said Zainal (2004). Kebijakan Publik. Jakarta: Pancur Siwah.

2. Adil, Hilman (1993). Hubungan Australia dengan Indonesia 1945-1962. Jakarta: Djambatan.

3. (1997). Kebijaksanaan Australia Terhadap Indonesia 1962-1966. Jakarta: CSIS.

4. Amri, Ahmad Almaududy (2012). Foreign Affairs and Defence Ministers Meeting Indonesia-Australia: Upaya dalam Meningkatkan Hubungan Bilateral di Bidang Keamanan. Jakarta: Universitas Indonesia.

5. Angraeni, Lisa (2006). Mengkaji Ulang Hubungan Australia dan Indonesia.

6. Kedutaan Besar RI Canberra (2003). Area Study Negara Australia. Canberra Australia: Kantor Atase Pertahanan RI. 
7. Kedutaan Besar RI Canberra (2008). Area Study Negara Australia. Canberra Australia: Kantor Atase Pertahanan RI.

8. Barnett, Michael dan Duvall, Raymond (2005). "Power in International Politics". In International Organization, Vol. 59, No. 1; pp. 39-75.

9. Bell, D., dan Wilson, H., (eds) (1991). Strange Neighbours: The Australian-Indonesia Relationship. Sydney: Allen \& Unmin.

10. Singh, Bhubhindar dan Tan, See Seng, (eds.) (2011). Defence Diplomacy in South East Asia From 'Boots' to 'Brogues': The Rise of Defence Diplomacy in Southeast Asia. Singapore: RSIS.

11. Buku Putih Departemen Pertahanan Australia 2000 (2000). AB Australia di Masa Depan. Terjemahan Departemen Pertahanan Indonesia. Jakarta: Australian Embassy.

12. Buzan, B. (1983). People, States and Fear: The National Security Problem in International Relations. North Carolina: University of North Carolina Press, Chapel Hill.

13. Buzan, B., dan Waever, O., dan de Wilde, J. (1998). Security: A New Framework for Analysis. London: Lynne Rienner Publishers.

14. Cheema, S. Shabbir dan Rondinelli, Dennis A. (1983), Implementing Decentralization Programmes in Asia: Local Capacity For Rural Development. Nagoya-Japan: UNCRD.

15. Clark, C. (1973). Australian Foreign Policy Toward Reassessment. Melbourn-Australia: Cassel.

16. Cottey, A., and Forste (2011). Defence Diplomacy in Southeast Asia: Trends, Prospects and Challenges. In Bhubhindar Singh, dan See Seng Tan, (eds.) Defence Diplomacy in South East Asia From 'Boots' to 'Brogues': The Rise of Defence Diplomacy in Southeast Asia. Singapore: RSIS.

17. Creswell, J. W. (2007). Research Design: Qualitative and Quantitative Approaches 2nd Edition. Thousand Oaks-CA: Sage Publication.

18. Djelantik, Sukawarsini (2015). Asia Pasifik: Konflik, Kerjasama, dan Relasi Antarkawasan. Jakarta: Buku OBOR.

19. Dunn, W. N. (1994). Public Polcy analysis. New Jersey-USA: Prentice Hall, Inc.

20. Dye, Thomas R. (1992). Understanding Public Policy. New Jersey: Englewood Cliffs.

21. (1976). What Governments Do, Why They Do It, What Difference It Make. Alabama-USA: University of Alabama, Tuscaloosa.

22. Easton, David (1965). A Framework for Political Analysis. New Jersey-USA: Prentice Hall.

23. Edward III., G. C., 1980. Implementing Public Policy. Washington D.C: Congressional Quartely Press.

24. Edwards III, G. C.; dan Sharkansky, Ira (1978). The Policy Predicament-Making and Implementing Public Policy. San Fransisco: W.H. Freeman and Company.

25. Evans, Gareth (1993). Australia's Foreign Relations in The World of the World 1990s. Melbourn: Melbourn University.

26. (1989). Australian Foreign Policy: Priorities in Changing World. Canberra: Australian Government Publishing Service.

27. Fry, G. (1991), Australia's Regional Security. Sydney: Allen \& Unwin.

28. Grant, Bruce (1983). The Australian Dilemma, A New Kind of Western Society. NSWAustralia: Macdonald Futura.

29. Grindle, Merilee S. (1980). Politics and Policy Implementation in the Third World. New Jersey: Princenton University Press.

30. Hegarty, David (1989). South Pasific Security Issues: An Australian Perspective 1987. Australia: Australian National University.

31. Jemadu, Aleksius (2006). "Kebijakan Politik dan Keamanan Australia di Kawasan Asia Pasifik”. Dalam Jurnal Luar Negeri, Volume 23 Nomor 2, BPPK Departemen Luar Negeri. Jakarta.

32. Jervis, Robert (1976). Perception and Misperception in International Politics. New Jersey: Princeton University Press, Princeton.

33. Jessica, Tuchman Mathews (1989). "Redefining Security". In Foreign Affairs, Vol.68, No.2, pp.167-177. 
34. Kaesorry, M Daril (2004). Hubungan Politik Pertahanan dan Keamanan Australia, Suatu Kajian Terhadap Stabilitas Keamanan Kawasan. Yogyakarta: Universitas Gadjah Mada.

35. Keating, Paul (2000), Engagement: Australia Forces the Asia Pasific. Sidney-Australia: Macmillan.

36. Kementerian Luar Negeri RI, 2008. Agreement between Australia and the Republic of Indonesia on the Framework for Security Cooperation, Mataram Lombok, 13 November 2006, Entered into Force, 7 February 2008.

37. Keputusan Presiden Ri Nomor 50 Tahun 1996 Tentang Pengesahan Persetujuan Antara Pemerintah Republik Indonesia Dan Pemerintah Australia Tentang Pemeliharaan Keamanan.

38. Keputusan Presiden Ri Nomor 128 Tahun 1999 Tentang Pencabutan Keputusan Presiden Nomor 50 Tahun 1996 Tentang Pengesahan Persetujuan antara Pemerintah Republik Indonesia dan Pemerintah Australia Tentang Pemeliharaan Keamanan.

39. Kompas, 2001. "Hubungan RI-Australia, Kepentingan Kedua Pihak".

40. Kitley, P., dan Chauve, R., dan Reeve, D., (eds) (1989). Australia di Mata Indonesia. Jakarta: PT Gramedia dan Kedutaan Besar Australia.

41. Larson, Eric.W, et al. (2008). Assesing Irregular Warfare: A Framework for Intelligence Analysis.

42. Lee, D. (1995). Search for Security: The Political Economy of Australia's Postwar Foreign and Security Policy. Sedney: Allen \& Unwin.

43. Lippmann, W. (1943). US Foreign Policy. Shield of the Republic Boston, Little, Brown.

44. Mazmanian, Daniel A., dan Sabatier, Paul A. (1983). Implementation and Public Policy. USA: Scott Foresman and Company.

45. Miles, Matthew B.; dan Huberrman, A. Michael; dan Saldana, Johnny; 2014. Qualitative Data Analysis: A Methods Sourcebook. Singapore: SAGE Publications Inc.

46. Mar'iyah, Chusnul (2005). Indonesia-Australia: Tantangan dan Kesempatan dalam Hubungan Politik Bilateral. Jakarta: Granit.

47. Nugroho, Riant (2014). Public Policy: Teori, Manajemen, Dinamika, Analisis, Konvergensi, dan Kimia Kebijakan. Jakarta: PT Elex Media Komputindo, Jakarta.

48. O'Hare, Martin, dan Reid, Anthony (1995). Australia dan Perjuangan Kemerdekaan Indonesia = Australia \& Indonesia's struggle for independence. Jakarta: Gramedia Pustaka Utama.

49. PP Pengganti UU RI Nomor 1 Tahun 2002 Tentang Pemberantasan Tindak Pidana Terorisme

50. Prasetyono, Edi (2006). "Faktor Keamanan Strategis dalam Hubungan RI-Australia". Dalam Jurnal Luar Negeri. Volume 23 Nomor 2, BPPK Departemen Luar Negeri, Jakarta.

51. Renouf, A. (1983). The Frightened Country. Melbourne: MacMillan Company.

52. Ripley, Randal B., Franklin, Grace A. (1982). Bureaucracy and Policy Implementation. Belmont: Dorsey Press.

53. Rosenau, James N. (ed.) (1961). International Politics and Foreign Policy: A Reader in Research and Theory. NY: The Free Press of Glencoe.

54. (1981). The Study of Political Adaptation. London: Frances Pinter (Publisher).

55. Sabatier, Paul (1986). "Top Down and Bottom Up Approaches to Implementation Research". In Journal of Public Policy 6, Jan.

56. Setiawati, Siti Muti"ah (2013). Relevansi Politik Luar Negeri Indonesia Bebas Aktif dalam Arsitektur Perubahan Tatanan Politik Internasional. Proceding Seminar Refleksi 65 Tahun Politik Luar Negeri Indonesia Bebas Aktif, Institute of International Studies. Yogyakarta: Universitas Gadjah Mada.

57. Sheridan, G. (1995). Living With Dragons: Australia Confronts Its Asian Destiny. Sydney: Allen \& Unwin.

58. Sinaga, Huminca (2006). Keharmoniasan Jakarta-Canberra Sulit di Prediksi.

59. Situmorang, Ridho F. (2015). "Pemutusan Sementara Hubungan Bilateral Antara Indonesia-Australia Terkait Penyadapan oleh Pemerintah Australia Ditinjau dari Hukum Internasional". Dalam JOM Fakultas Hukum, Volume 2 Nomor 1 Februari 2015 
60. Suryadinata, Leo (1998). Politik Luar Negeri Indonesia di Bawah Soeharto. Jakarta: LP3ES.

61. Takur, Ramesh (1989). Australia, New Zeland and Small States in World Order. Australia: Australia National University.

62. UU RI Nomor 3 Tahun 2002 Tentang Pertahanan Negara

63. UU RI Nomor 47 Tahun 2007 Tentang Pengesahan Perjanjian Antara Republik Indonesia dan Australia Tentang Kerangka Kerja Sama Keamanan (Agreement between the Republic of Indonesia and Australia on The Framework for Security Cooperation).

64. Wangke, Humphrey (2014). Info Singkat Hubungan Internasional, Kajian Singkat Terhadap Isu-isu Terkini, Efektivitas Kesepakatan Code of Conduct Indonesia-Australia.

65. William, T. Tow (2001). Asia-Pasific: Strategic Relations: Seeking Convergent Security. Cambridge: Cambridge University Press.

66. Wise, M. William (2005). Indonesia's War on Terror. United States-Indonesia Society.

67. Wolfers, Arnold (1952). "National Security as an Ambiguous Symbol". In Political Sciences Quarterly, Vol. 67, No. 4. pp. 481-502

68. Yudhoyono, Susilo Bambang (2002). Save Our Country From Terrorism, Coordinating Ministry for Political and Security Affairs, Jakarta. 